
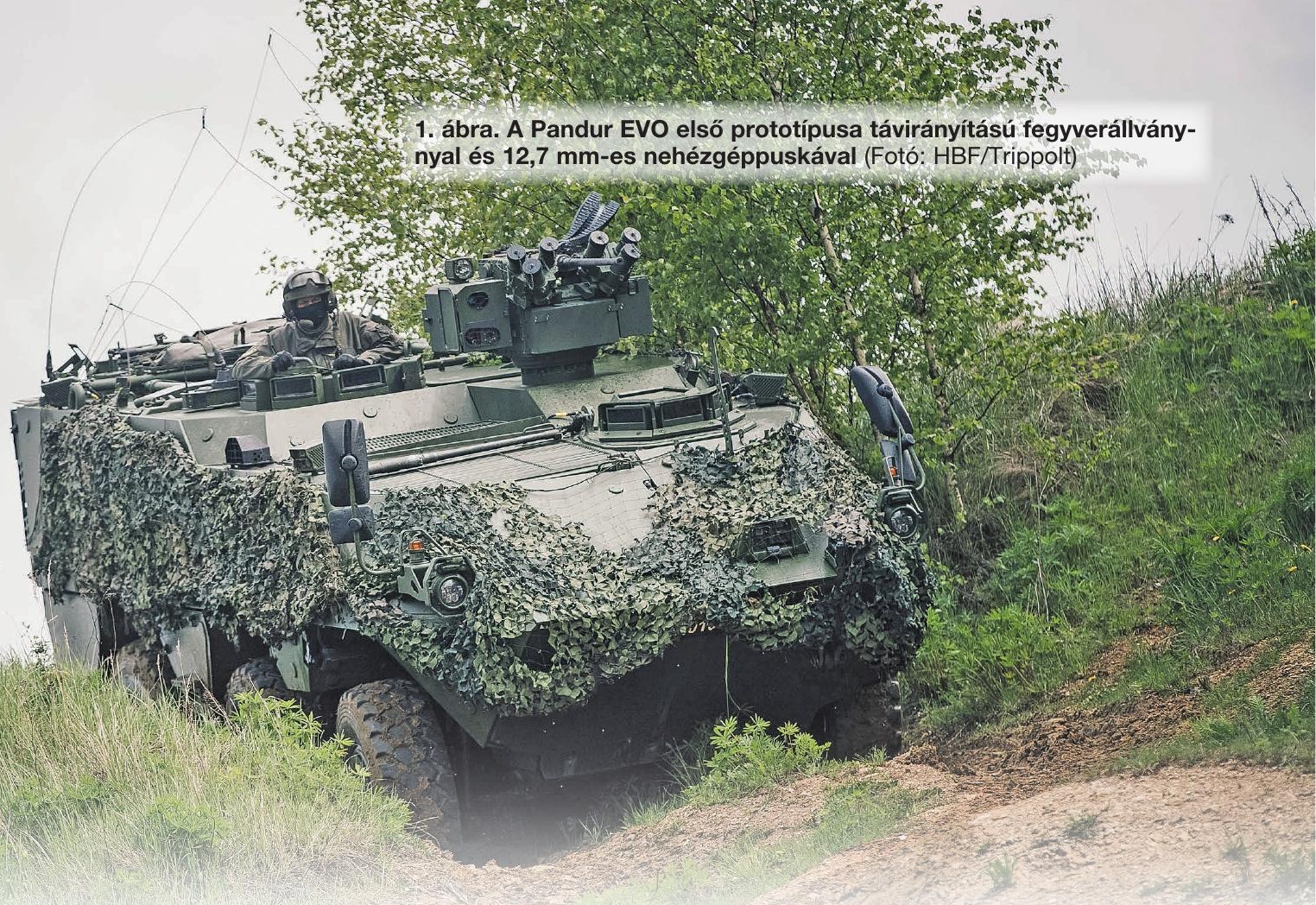

\title{
A Pandur Evolution páncélozott szállító harcjármű fejlesztése
}

A z Az Osztrák Szövetségi Hadsereg (Österreichisches Bundesheer) vezetése 2016 decemberében írta alá a szerződést a General Dynamics European Land Systems - Steyr GmbH-val (továbbiakban GDELS-Steyr) 105 millió euró értékben 34 db Pandur Evolution 6×6 kerékképletű (továbbiakban Pandur EVO) páncélozott szállító harcjármű 2020-ig történő legyártásáról és szállításáról. (A Bundesheer fontos piac a Bécs-simmeringi székhelyű GDELSSteyr számára.) Az első prototípust - más jármútípusokkal együtt (Dingó 2A3, Dingó 2A4) - az osztrák védelmi minisztérium 2018. júniusban, Bécsben mutatta be a nyilvánosságnak.

Miután befejeződtek a Pandur EVO prototípusának ballisztikai, akna-, repesz- és IED-védettségi tesztjei, 2019. január hónapban a GDELS-Steyr csapatpróbára átadta az első öt harcjárművet a stájerországi Strass helyőrségben az osztrák 17. vadász zászlóalj számára. A zászlóalj a projektcsapat tagjaként, annak indulásától kezdve együttmü-

ÖSSZEFOGLALÁS: A GDELS-Steyr GmbH Pandur EV0 6×6-os kerékképletú páncélozott szállitó harcjárműve a Pandur harcjármúcsalád új fejlesztésú tagja. Kiváló mobilitása - kompakt jármúmérettel, ballisztikai védelemmel és újonnan fejlesztett, függetlenített közbenső padlós aknavédelemmel kombinálva - kategóriájában a magas túlélőképességet biztositó harcjármúvek közé sorolja.

KULCSSZAVAK: GDELS-Steyr, Pandur EV0 6×6, páncélozott szállító harcjármü, ballisztikai- és akna elleni védelem, robbanásérzékelő- és hatáscsökkentő rendszer, ABV-védelem, távirányítású fegyverállvány, $360^{\circ}$-os körkörös jármúvezetői figyelőrendszer. ködött az új koncepció kialakításához szükséges alkalmazói követelmények összeállításában. A legfontosabb követelmények között szerepelt a magas szintű ballisztikai és akna elleni védelem, az elektronikus architektúra javítása, valamint a C-130 Hercules szállító repülőgépekkel történő szállíthatóság biztosítása.

Osztrák katonai szakportálok szerint a Pandur EVO koncepciót több tényező is motiválta. Egyfelől a kor műszaki színvonalának megfelelő ballisztikai és aknák elleni védelem (különös tekintettel az IED-ek elleni védelemre, és az erők megóvására), másfelől a jármű deszant terének bővítése, a 3 fős személyzeten felül 8 lövészkatona befogadására való alkalmassá tétele. A helyigényt biztosítandó, a jármű döntött oldalfalait meredekebbre, szinte merőlegesre változtatták. A kétszárnyas hátsó ajtó helyett a jármű új hidraulikus hátsó rámpát kapott, megkönnyítve a „harcjárműre, illetve harcjárműről szállás" végrehajtását.

ABSTRACT: The $6 \times 6$ wheeled armoured personnel carrier Pandur EVO manufactured by the GDELS-Steyr GmbH is the recently developed member of the Pandur fighting vehicle family. Combined with compact vehicle dimensions, ballistic protection and independent mid-floor anti-mine protection makes it one of the high-survivability combat vehicles in its category.

KEY WORDS: GDELS-Steyr, Pandur EV0 $6 \times 6$, armoured personnel carrier, ballistic and anti-mine protection, explosion detection and effect reduction system, ABC protection, remotely controlled weapon platform, 360 degree driver's surround view monitoring system

\footnotetext{
Nyá. mérnök alezredes. ORCID: 0000-0002-3732-4573
} 


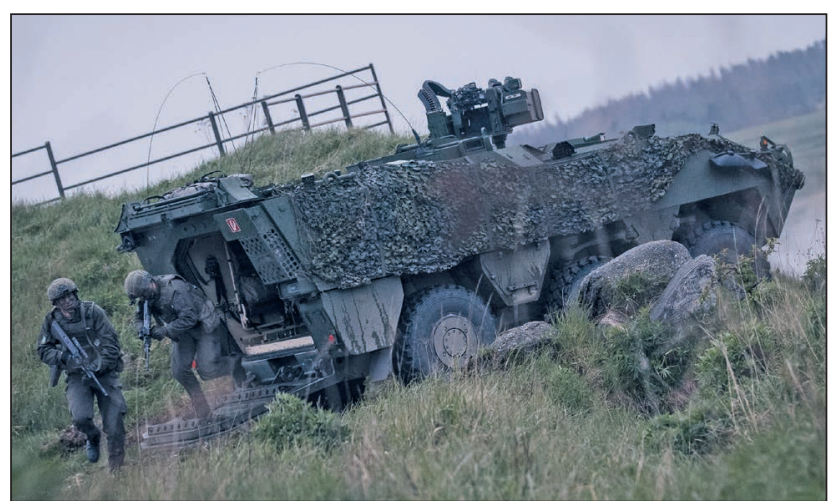

2. ábra. Új hidraulikus hátsó rámpa segíti a lövészkatonák gyors be- és kiszállását (Fotó: HBF/Trippolt)

A Pandur EVO a Bundesheerben 1996-ban rendszeresített és többször korszerűsített (többek között Elbit lézeres fenyegetésérzékelő és figyelmeztető rendszerrel ellátott), 6×6-os járműverzió legújabb modifikációja. Inkább új fejlesztést jelent, mint modernizálást. Általános elrendezése megegyezik a Haditechnika 2017/1. számában már bemutatott bázisváltozattal, ahol a vezető balról, a dízelmotor jobbról, a deszanttér hátul kapott helyet. A futómű-konfiguráció - a 6×6-os változatok logisztikai megegyezősége (családelvűsége és a csereszabatossága) megőrzésének érdekében - változatlan maradt.

Erőforrása egy Cummins ISLe 450 típusú, elektronikus vezérlésű, hathengeres soros elrendezésű, központi befecskendezéses, 8,9 l-es 335 kW (2200/min fordulatszámon) teljesítményű dízelmotor. Csúcsnyomatéka 1627 Nm (1300/min fordulatszámon). Ez a kifejezetten katonai célokra fejlesztett motor hajtja a nyugaton gyártott hasonló típusú harcjárművek $70 \%$-át. Üzemanyaga gázolaj vagy kerozin (F34). A jármű magas maximális motorteljesítménye (335 kW) és viszonylag alacsony harci tömege (18,3 t) körülbelül $18 \mathrm{~kW} / \mathrm{t}$ teljesítmény/tömegarányt eredményez.
A $18 \mathrm{~kW} / \mathrm{t}$ érték megfelel a világ egyik legjobb harckocsija, a Leopard 2-es teljesítmény/tömegarányának.

A motor által leadott hajtóerő egy elektronikusan vezérelt, hatsebességes automata (hat előre- és egy hátrameneti fokozatú) ZF Ecomat nyomatékváltóba kerül. A váltó részét képezi egy elektronikusan szabályozható retarder egység, amely hatékonyan segíti a jármú lassítását lejtmenetben. A váltót összekapcsolták egy - összkerékhajtást biztosító - GDELS VG1400 osztóművel, amely lehetővé teszi az országúti és a terepfokozat közötti szinkronizált váltást. A múvelet végrehajtásához nem szükséges megállni, menet közben is végrehajtható. Az ADM (Automatic Drivetrain Management System) automata hajtásláncvezérlés a terephez igazodva a kerékkipörgési és kormányzási szögértékek, valamint a gáz- és fékpedál helyzete alapján automatikusan be- vagy kiiktatja az összkerékhajtást. A jármű terepjáró képessége - a menet közben működtethető CTIS (Central Tire Inflation System) központi abroncsnyomás-szabályzó rendszert az ADM-mel együtt alkalmazva - meghaladja a harcjárművek átlagát. $A$ futómű hat gumiabroncsában a levegőnyomás a terepviszonyoknak megfelelően egyszerre, vagy tengelyenként külön-külön szabályozható. Defekt esetén run-flat (defekttűrő) gumiabroncsok és vészfutó-gyűrűk biztosítják, hogy a jármúvek csökkentett sebességgel egy meghatározott távolságig továbbra is mozgóképesek maradjanak. A végsebesség müúton $105 \mathrm{~km} / \mathrm{h}$, tartós legnagyobb sebesség $95 \mathrm{~km} / \mathrm{h}$. Az üzemi fék ABS blokkolásgátló rendszerű, belülről hűtött kétkörös tárcsafék. A fokozott villamos energiaigényt biztosítandó, a Pandur EVO-t a német Niehoff cég generátorával is ellátták.

A vezetést az Elbit Systems $360^{\circ}$-os, körkörös figyelőrendszere segíti, amelyet először építettek be kerekes páncélozott harcjármübe. A rendszer lehetővé teszi a jármű kamerák segítségével történő vezetését. A teljes rendszer hét nappali és éjszakai kameracsoportból áll, közülük a vezető szabadon választhat. A kameramodulok vízszintes látótere $83^{\circ}$, függőleges látómezeje körülbelül $60^{\circ}$. Saját monitorán a járműparancsnok és a toronylövész is figye-

3. ábra. Pandur EVO menetoszlop egy csapatpróbán (Fotó: HBF/Trippolt)

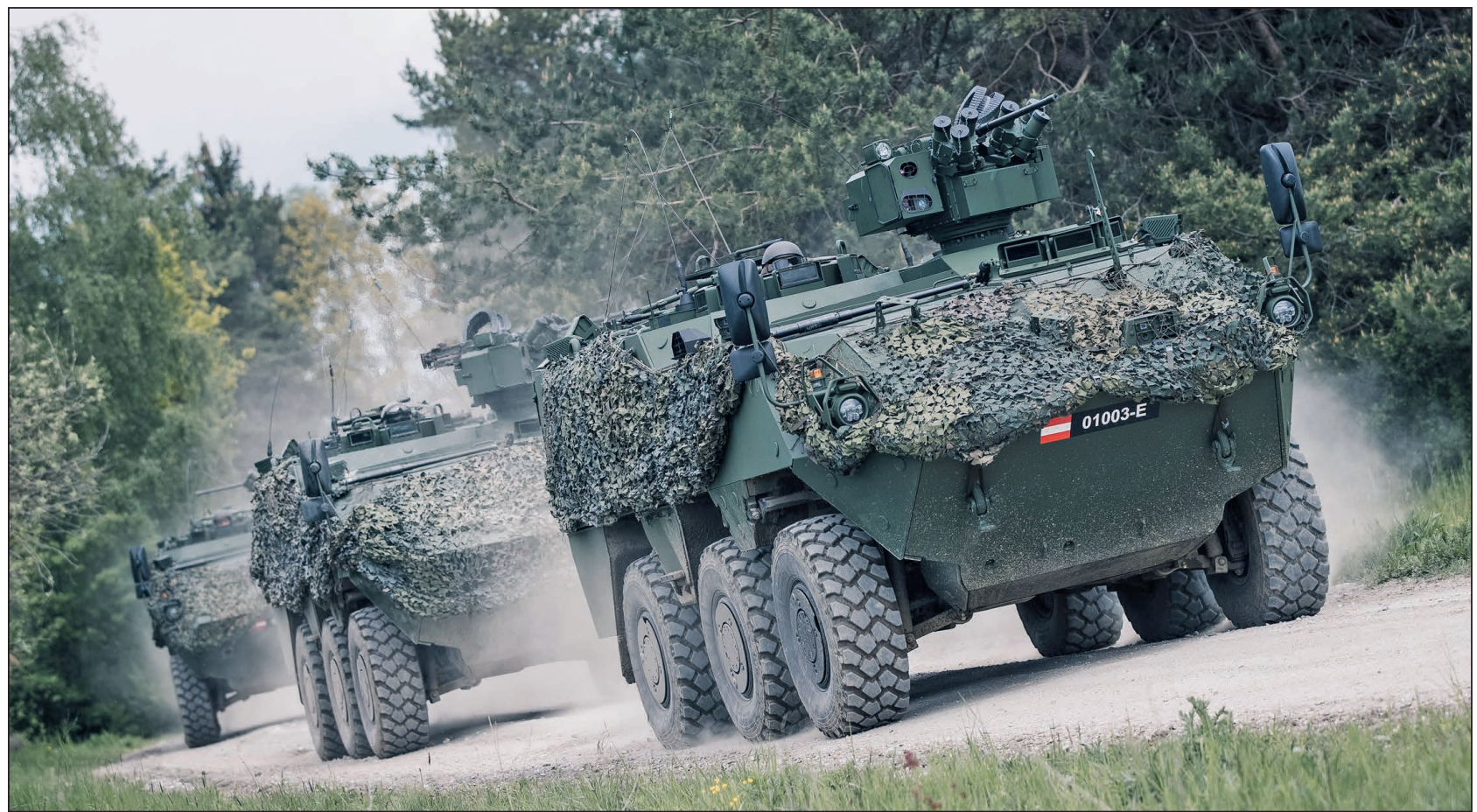




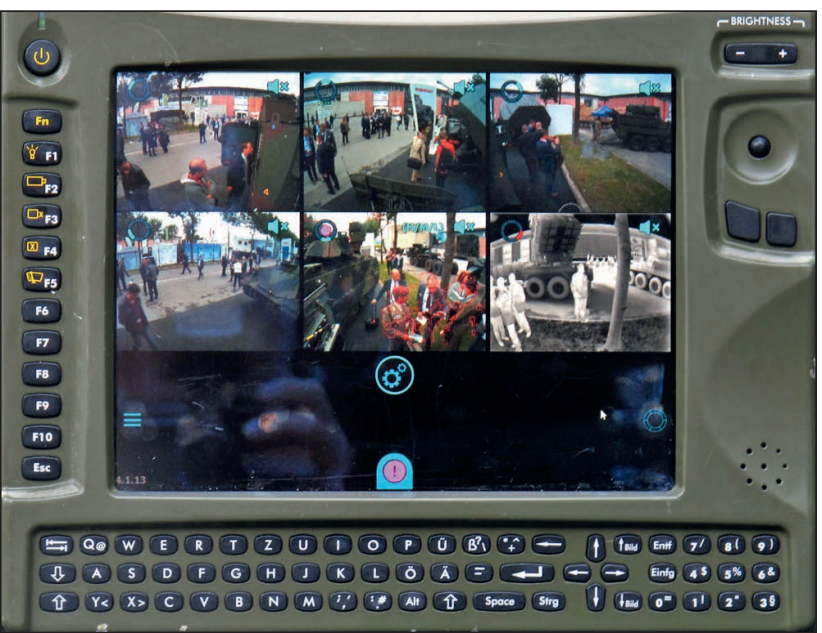

4. ábra. Az ELBIT cég jármúvezetést segítő $360^{\circ}$-os figyelörendszerének monitora (Fotó: HBF/Trippolt)

lemmel kísérheti a terepet. A rendszer video-mozgásérzékelő funkcióra is képes.

A Pandur EVO megnövelt moduláris ballisztikai, akna, repesz és IED elleni - NATO STANAG 4569 szabvány szerinti - védelmét innovatív hegesztett páncéltest biztosítja, függetlenített közbenső padlóval, a padlózattól elválasztott függesztett aknaálló ülésekkel, valamint robbanásérzékelő és hatáscsökkentő rendszerrel. A páncéltest ballisztikai védettsége tovább növelhető a német IBD Deisenroth Engineering cég kiegészítő páncélkészletének adaptálásával. A páncélzat esetleges átütésekor aktiválódó robbanáselfojtó rendszer megakadályozza az üzemanyag vagy a hidraulikafolyadék stb. robbanásszerű reakcióját.

További védelemnövelő eszköz lehet a távirányítású IEDek elleni CVRJ (CREW Vehicle Receiver / Jammer) járműbe építetett elektronikai zavaró-rendszer. A CVRJ képes az elektromágneses környezet folyamatos felderítésére, a rádiófrekvenciás veszélyforrások érzékelésére és zavarására, többek között az IED eszközök robbanása mobiltelefon által történő kiváltásának megakadályozására. A Pandur EVO védelmét a $360^{\circ}$-os, körkörös látó- és figyelő kamerarendszer, valamint az ABV szűrő- és szellőztető berendezés teszi teljessé.

A jármű Elbit ORCWS-M (Overhead Remote Controlled Weapons Station-Multi) elektromos távirányítású fegyverállványt kapott. A fegyverállvány különböző fegyverekkel, például M2NV 12,7 mm-es nehézgéppuskával, MG74 7,62mmes géppuskával, vagy $40 \mathrm{~mm}$-es automata gránátvetővel, (opcionálisan 7,62 mm-es géppuskával és 40 mm-es auto-

5. ábra. Deszanttér hátulnézeti képe, függesztett aknaálló ülésekkel (Fotó: HBF/Trippolt)

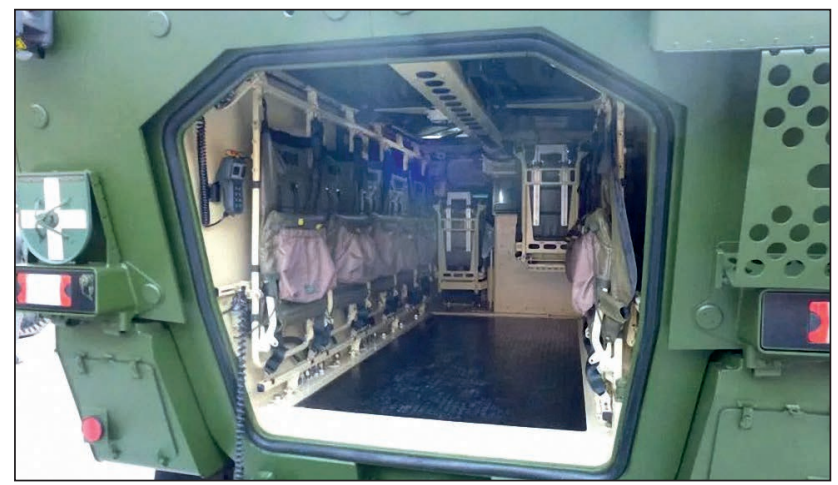

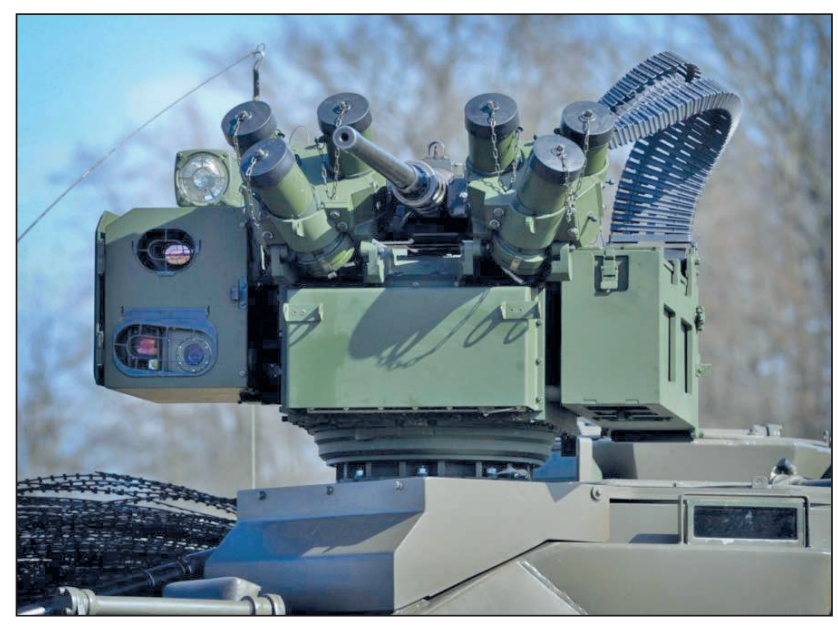

6. ábra. 12,7 mm-es nehézgéppuskával szerelt Elbit/ESL ORCWS-M fegyverállvány (Fotó: HBF/Trippolt)

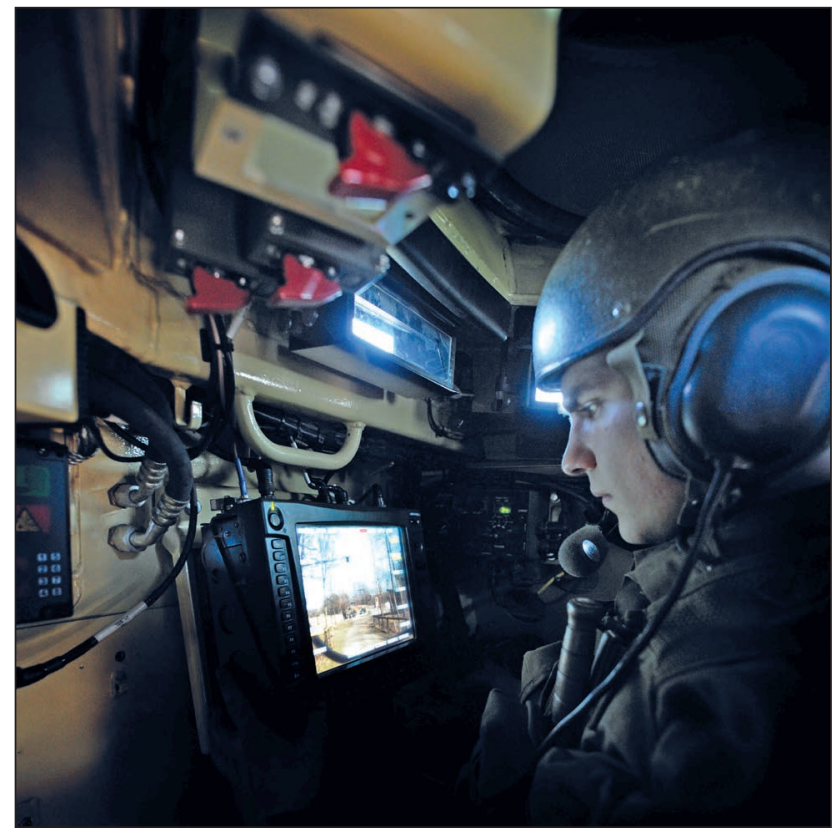

7. ábra. A célzást és a tüzelést a toronylövész a monitoron megjelenő kép alapján végzi (Fotó: HBF/Trippolt)

mata gránátvetővel), valamint ködgránátvetőkkel szerelhető fel. A célfelderítést és -befogást biztosítandó, a fegyverállványt időjárás-független stabilizált elektrooptikai csomaggal, nappali kamerával, termikus éjjellátó kamerával, lézertávmérővel és keresőfénnyel látták el. Az ORCWS-M fegyverállvány kiegészítő funkciója az automatikus célkövetés, valamint a manuális müködtetés áramkimaradás esetén. A fegyverállvány nagy tűzerőt, kiváló nappali és éjszakai megfigyelést és tüzelési lehetőséget nyújt, alkalmassá téve a Pandur EVO-t a városi harcra is. A géppuska működtetését a toronylövész a fegyverállvány termináljáról botkormánnyal (joystickkal) végzi, nem szükséges elhagynia a biztonságot nyújtó jármú belsejét.

A Pandur EVO-k egymás közötti, illetve a járműveken belüli kommunikációs kapcsolatok biztosítására $30-88 \mathrm{MHz}$ (opcionálisan 30-108 MHz) frekvenciatartományú, frekvenciaugrásos adásmódú erősítővel, $50 \mathrm{~W}$ teljesítményű - a Bundesheer CONRAD (Combat Net Radio) rádióhálózatához tartozó - legújabb generációs RT-9101A és CNR$710 A$, vagy Tadiran CNR-9000 és PNR-500AT járműfedél- 
1. táblázat. A Pandur EVO föbb múszaki paraméterei

\begin{tabular}{|c|c|}
\hline Gyártó & General Dynamics European Land Systems - Steyr GmbH \\
\hline Típus & Pandur $6 \times 6$ \\
\hline Hajtásmód & $6 \times 4$ és $6 \times 6$ \\
\hline Járműkategória & Páncélozott szállító harcjármű \\
\hline Személyzet & 3 fő személyzet és 8 fő lövészkatona \\
\hline \multicolumn{2}{|c|}{ Tömegadatok } \\
\hline Saját tömeg (ballisztikai védelem és személyzet nélkül) & $15000 \mathrm{~kg}$ \\
\hline Összes tömeg & $19000 \mathrm{~kg}$ \\
\hline Harci tömeg & $18300 \mathrm{~kg}$ \\
\hline \multicolumn{2}{|r|}{ Méretek } \\
\hline Teljes hosszúság & $6500 \mathrm{~mm}$ \\
\hline Teljes szélesség & $2670 \mathrm{~mm}$ \\
\hline Magasság & $2182 \mathrm{~mm}(+/-30 \mathrm{~mm})$ \\
\hline Hasmagasság & $410 \mathrm{~mm}(+/-30 \mathrm{~mm})$ \\
\hline Lépcsőmászó képesség & $500 \mathrm{~mm}$ \\
\hline \multicolumn{2}{|c|}{ Erőforrás } \\
\hline Erőforrástípus & Hathengeres Cummins ISLe 450 dízelmotor \\
\hline Nyomaték & 1627 Nm 1300/min fordulatszámon \\
\hline Teljesítmény & 335 kW 2200/min fordulatszámon \\
\hline \multicolumn{2}{|c|}{ Erőátvitel } \\
\hline Sebességváltó & $\begin{array}{l}\text { Elektronikus vezérlésű automata sebességváltó retarderrel, } \\
6 \text { előre és } 1 \text { hátra fokozattal }\end{array}$ \\
\hline Osztómű & GDELS VG 1400 kétfokozatú osztómű \\
\hline \multicolumn{2}{|c|}{ Képességek } \\
\hline Maximális sebesség közúton & $105 \mathrm{~km} / \mathrm{h}$ \\
\hline Tartós legnagyobb sebesség közúton & $95 \mathrm{~km} / \mathrm{h}$ \\
\hline Emelkedő-leküzdő képesség & $60 \%$ \\
\hline Lejtőleküzdő képesség & $40 \%$ \\
\hline Hatótávolság & $650 \mathrm{~km}$ \\
\hline Árokáthidaló képesség & $1,1 \mathrm{~m}$ \\
\hline Gázlóképesség & $1,5 \mathrm{~m}$ \\
\hline Vasúti szállíthatóság & Igen (STANAG 2832 szerint) \\
\hline Közúti szállíthatóság & Igen (25 t-s trélerrel) \\
\hline Légi szállíthatóság & Igen (C-130 Hercules szállító repülőgéppel) \\
\hline & Védelem \\
\hline
\end{tabular}

Moduláris ballisztikai védelem, STANAG 4569 szerinti akna- és IED-védelem, padlózattól elválasztott aknaálló ülésekkel, ABV-védelem, és tűzvédelem automata oltóberendezésekkel.

\section{Opcionális felszerelések}

Ügyfélspecifikus C4ISR (Command, Control, Communications, Computers, Intelligence, Surveillance and Reconnaissance) vezetési és felderítési szakterülethez kapcsolódó valamennyi rendszer; vonófej-csatlakozókészlet, csörlő és $360^{\circ}$-os kamerakészlet. 


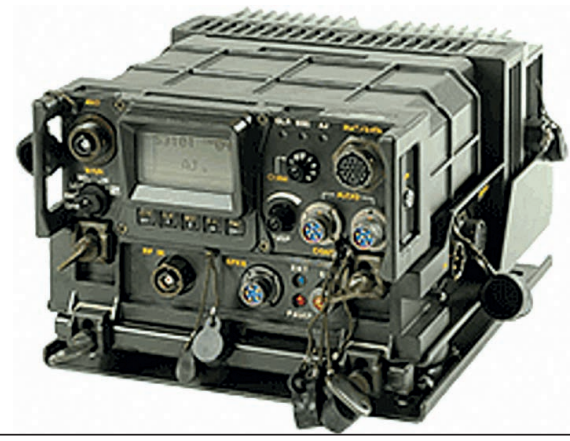

8. ábra. Tadiran CNR-9000 információvédett rádió adó-vevó (Fotó: HBF/Trippolt)

zeti rádiók, illetve a Cobham AN (VIC-3 ROVIS) jármü intercom rendszerek szolgálnak. A Bundesheer CONRAD rádiókommunikációs rendszere high-tech technológia, amelyet információvédett beszéd- és adatkommunikációs képesség, felhasználóbarát kezelés, és magas fokú flexibi¿ิ̀ litás jellemez.

A háromtengelyes Pandur EVO változat kedvező manőverező képessége a $8 \times 8$ kerékképletű páncélozott harcjárművekkel szemben erdős-hegyes terepen elvitathatatlan. Védettségét közvetve befolyásolja kis fizikai mérete, hoszszúsága, szélessége és magassága. A kisebb méretű jármű nehezebben deríthető fel, könnyebben foglalhat fedezéket, és nehezebben vehető célba optikai irányzékú fegyverekkel. A Bundesheer 34 db-os Pandur EVO megrendelése arra utal, hogy az Osztrák Szövetségi Hadsereg a meglevő 71 db-os Pandur 6×6-os flottáját növelni kívánja. Elképzelhetö, hogy a további megrendelések tartalmaznak majd nehézfegyverzetű, sebesültszállító és harctéri kommunikációs felszereltséggel rendelkező járműveket is.
A Pandur EVO kétségkívül az osztrák fegyveres erők legmodernebb, sokoldalúbb és legjobban védett kerekes páncélozott harcjárműve.

\section{ForRásOK}

GENERAL DYNAMICS European Land Systems: Wheeled Armored Vehicle PANDUR 6×6;

Mönch Publishing Group. „Eurosatory 2018: GDELS \&

Austria Detail PANDUR" Letöltve: 2019. 11. 14. https://www.monch.com/mpg/news/land/3670-eurogdels-8.html;

Hubert, Norbert. „Das Arbeitstier” Letöltve: 2019.11.14. https://www.truppendienst.com/themen/beitraege/ artikel/das-arbeitstier/;

Pandur EVO - Doppeladler.com fórumtopik. Letöltve. 2019. 11. 14. https://www.doppeladler.com/da/forum/ viewtopic. php? $\mathrm{t}=58$ \&start $=150$;

BMPD. „Первый бронетранспортер Pandur EVO” https://bmpd.livejournal.com/3231384.html;

Military Leak. „Austrian Army Pandur Evo 6×6” Letöltve 2019. 11. 14. https://militaryleak. com/2019/01/25/austrian-army-pandur-evo-6x6/;

Army Guide. „PANDUR EVO” Letöltve: 2019. 11. 14. www.army-guide.com/eng/product6001.html;

M. M. „Austrian Pandur projects progression” Below The Turret Ring https://below-the-turret-ring.blogspot.com/2017/06/ austrian-pandur-projects-progression.html;

Unser Heer. „Bundesheer modernisiert Mannschaftstransportpanzer „Pandur”” letöltve: 2019. 11. 14. www.bundesheer.at/cms/artikel.php?ID=7632;

Doppeladler.com. „Projektstart Pandur EVO” www.doppeladler.com/da/news/projektstart-pandur-evo/.

\section{HM ZRÍNYI TÉRKÉPÉSZETI ÉS KOMMUNIKÁCIÓS SZOLGÁLTATÓ KÖZHASZNÚ NKFT. Telephely: 1024 Budapest II., Szilágyi Erzsébet fasor 7-9. • 1276 Budapest 22, Pf. $85 ・ 5$ I +36 (1) 336-2030 •www.topomap.hu • hm.terkepeszet@ topomap.hu

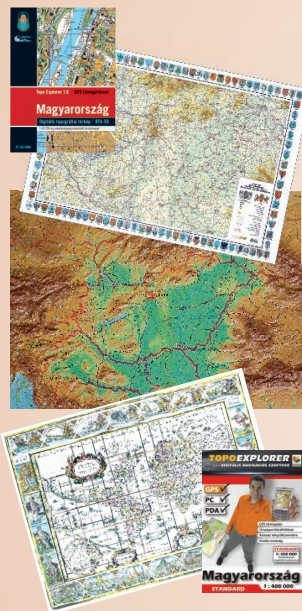 \\ - Topográfiai térképek \\ - Fakszimile térképek \\ - Atlaszok, város- és autótérképek \\ - Falitérképek \\ - Szabadidótérképek \\ - Léǵiforgáalmi térképek \\ - Munkatérképek \\ - Dombortérképek \\ - Digitális térképészeti adatbázisok \\ - Eǵvéb digitális termékek \\ - Légifilmtári szolgáltatások \\ ÜGYFÉLSZOLGÁLAT ÉS TÉRKÉPBOLT: \\ 1024 Budapest III., Fillér u. 14.

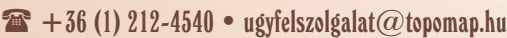 Nyitva tartás: hétfö-péntek $9.00-15.00$ \\ - PrePress - Nyomdai elökészítés \\ - szöveg', grafika- és képfeldolgozás, kiadványszerkesztés \\ - ellenőrzó nyomatok, digitális proofok elóállítása \\ - bel-és kültéri tablók, bannerek nyomtatása \\ - hagyományos és elektronikus montírozás, színrebontás \\ - nyomóformák elóállitása nyomdai filmról, illetve CTP-technológiával \\ - Gyorssokszorosítás - színes és fekete-fehér másolás/nyomtatás 330 x 487 mm méretig \\ - Press - Nyomtatás \\ - ofszetnyomtatás négy-, illetve hatszínnyomó gépeken, 89 x 126 cm méretig \\ - PostPress - Kötészeti feldolgozás \\ - felületnemesítés fóliázással, laminálással 167 cm szélességig \\ - hajtogatás, spirálozás, sorszámozás \\ - összehordás, irkakészítés, ragasztókötés \\ - kasírozás, táblakészítés, aranyozás \\ - szortiment könyvkötészet \\ - Vákuumformázás \\ - vákuumformázó szerszámok, terepasztalok elóállitása CNC-technológiával - vákuumformázás}

